\title{
Improvement of insulin resistance by Cyanidin 3-glucoside, anthocyanin from black beans through the up-regulation of GLUT4 gene expression
}

\author{
Tetsuya Inaguma', Junkyu Han ${ }^{1,2}$, Hiroko Isoda ${ }^{1,2^{*}}$ \\ From 22nd European Society for Animal Cell Technology (ESACT) Meeting on Cell Based Technologies \\ Vienna, Austria. 15-18 May 2011
}

\section{Introduction}

Black beans have been suggested to have a protective effect against obesity. Cyanidin 3-glucoside (Cy-3-G) belongs to the flavonoid class of molecules and is a member of the anthocyanin family that is present in black beans. Some studies indicated that Cy-3-G from black beans may be beneficial for the improvement of obesity and type II diabetes. It has been reported that Cyanidin 3-glucoside ameliorates insulin sensitivity due by down-regulating the retinol binding protein 4 expression in diabetic mice [1]. Accumulation of neutral lipids, triglyceride (TG) in particular, is highly related to the development of insulin resistance and its consequences, such as type II diabetes. Lipid droplet size regulation is central in the regulation of metabolism and in adipocytokines secretion such as TNF- $\alpha$ and adiponectin $[2,3]$. However, little is currently known about how Cy-3-G influences adipocyte differentiation and insulin resistance in 3T3-L1 adipocytes. The purpose of the present study was to determine the effects of Cy-3-G on GLUT4 gene expression to improve insulin resistance in 3T3-L1 adipocytes.

\section{Materials and methods}

\section{Cell culture and treatment}

Adipocytes, 3T3-L1 cells (Riken Cell Bank, Ibaraki, Japan), were maintained in Dulbecco's modified Eagle's medium (DMEM) (Sigma Chemical Co, St. Louis, MO, USA) supplemented with $10 \%$ fetal bovine serum (FBS)

\footnotetext{
*Correspondence: isoda.hiroko.ga@u.tsukuba.ac.jp

${ }^{1}$ Graduate School of Life and Environmental Sciences University of Tsukuba, Tsukuba, Japan

Full list of author information is available at the end of the article
}

(Biowest, Miami, FL, USA, Japan) and 1\% 5,000 units/ml penicillin, 5,000 $\mathrm{\mu g} / \mathrm{mL}$ streptomycin (PS) (Lonza Walkersville, MD,USA) and incubated in $37{ }^{\circ} \mathrm{C}$ in $5 \% \mathrm{CO}_{2}$. For adipocyte differentiation, 3T3-L1 cells were cultured at $3.0 \times 10^{5}$ cells/well in 6 -well plates. Cells were maintained until full confluence, which is often around $48 \mathrm{~h}$, prior to treatment,. And then, cells were treated with differentiation medium containing Dexamethazone (DEX) Solution, 3-Isobuthyl-1-Methylxanthine (IBMX) Solution, Insulin Solution, and Cy-3-G. DEX Solution, IBMX Solution, and Insulin Solution were purchased from Cayman Chemicals (Ann. Arbor, MI, USA). Cy-3$G$ derived from black soybean was purchased from Fujicco Co., Ltd. (Kobe, Japan). After $72 \mathrm{~h}$ of induction, medium was changed to DMEM containing insulin and Cy-3-G was added every 2 days. After 4 days of incubation from the initiation of differentiation, bioassays were performed.

\section{RNA extraction and real-time PCR}

Total RNA was isolated from the 3T3-L1 cells using ISOGEN (Nippon Gene, Tokyo, Japan) according to the manufacturer's instructions. The integrity of the RNA extracted from all samples was verified and quantified using NANO DROP 2000 (Agilent Technologies, CA). Total RNA was used for the single strand cDNA synthesis with a cDNA synthesis kit, SuperScript ${ }^{\mathbb{B}}$ III Reverse Transcriptase. Gene expression levels were analyzed by quantitative real-time PCR, using the Applied Biosystems 7500 FAST INSTURMENT (Applied Biosystems, Foster City, CA, U.S.A.). The oligonucleotide primers of mouse were obtained from Applied Biosystems (Foster City, CA, U.S.A.). The cDNA was denatured at $95{ }^{\circ} \mathrm{C}$ 
Table 1 Effect of Cy-3-G on the gene expression of GLUT4 in 3T3-L1 adipocytes.

\begin{tabular}{cc}
\hline Sample & $\begin{array}{c}\text { Relative GLUT4 gene expression level (\% of } \\
\text { Control) }\end{array}$ \\
\hline Control & $100 \pm 1.5$ \\
Cy-3-G $20 \mu M$ & $208.2 \pm 1.4^{*}$ \\
Cy-3-G 100 & $226.57 \pm 15.2^{*}$ \\
HM & \\
\hline
\end{tabular}

Cy-3-G significantly induced the gene expression of GLUT4 in a dosedependent manner. ${ }^{*} p<0.05$ (vs Control)

for $10 \mathrm{~min}$, followed by 40 cycles of PCR $\left(95^{\circ} \mathrm{C}, 15 \mathrm{sec}\right.$; $60{ }^{\circ} \mathrm{C}, 60 \mathrm{sec}$ ).

\section{Results and discussion}

In Cy-3-G-treated cells, the number of droplets increased, while the lipid droplet size decreased. Cy-3-G significantly promoted the mRNA expressions of peroxisome proliferrator-activated receptor- $\gamma(\operatorname{PPAR} \gamma)$ [4], CCAAT/enhancer binding protein $\alpha(\mathrm{C} / \mathrm{EBP} \alpha)$ [4], and glucose transport 4 (GLUT4) [Table 1] in differentiated 3T3-L1 cells. PPAR $\gamma$ and C/EBP $\alpha$ mainly control adipocyte differentiation. GLUT4 takes in glucose on cell membrane. According to the results, Cy-3-G promotes adipocyte differentiation and uptake of glucose in a dose-dependent manner. In the present study, the concentrations of Cy-3-G treated were $20 \mu \mathrm{M}$, and $100 \mu \mathrm{M}$. $\mathrm{Cy}-3-\mathrm{G}$ at $20 \mu \mathrm{M}$, and $100 \mu \mathrm{M}$ significantly decreased TNF- $\alpha$ concentration and ROS production, and increased the adiponectin concentration in differentiated 3T3-L1 cell in a dose-dependent manner [4]. These effects suggest that Cy-3-G would contribute to the improvement of insulin resistance and its consequences. However, when we utilize black beans as food, the doses of Cy-3-G in black beans would be lower than the concentrations that we used in this study. Therefore, the study on the effects of Cy-3-G at lower concentrations, such as $1 \mu \mathrm{M}, 5 \mu \mathrm{M}$ and $10 \mu \mathrm{M}$, on adipocyte differentiation and adipocytokines secretion in differentiated 3T3-L1cells will be needed. Also, the anti-fat effects of Cy-3-G in vivo using diabetic model mice have not yet been widely reported. From our study, Cy-3-G derived from black bean as a food factor is expected to prevent life style-related disease.

\section{Conclusion}

Cy-3-G has the potential to improve insulin resistance and its consequences in 3T3-L1 adipocytes through the up-regulation of GLUT4 gene expression. Additional study on insulin resistance using 3T3-L1and anti-fat effect using diabetic model mice will be needed to verify these results in vivo.

\section{Acknowledgement}

This research was partially supported by JST-JICA's Science and Technology Research Partnership for Sustainable Development (SATREPS).

\section{Author details}

'Graduate School of Life and Environmental Sciences University of Tsukuba, Tsukuba, Japan. ${ }^{2}$ Alliance for Research on North Africa (ARENA) University of Tsukuba, Tsukuba, Japan.

Published: 22 November 2011

\section{References}

1. Sasaki R, Nishimura N, Hoshino H, Isa Y, Kadowaki M, Ichi T, Tanaka A, Nishiumi S, Fukuda I, Ashida H, Horio F, Tsuda T: Cyanidin 3-glucoside ameliorates hyperglycemia and insulin sensitivity due to downregulation of retinol binding protein 4 expression in diabetic mice. Biochem Pharm 2007, 74:1619-1627.

2. Okuno A, Tamemoto H, Tobe K, Ueki K, Mori Y, Iwamoto K, Umesono K, Akanuma Y, Fujiwara T, Horikoshi H, Yazaki Y, Kadowaki T: Troglitazone increases the number of small adipocytes without the change of white adipose tissue mass in obese Zucker rats. J Clin Invest 1998, 101:1354-1361.

3. Kadowaki T: Insights into insulin resistance and type 2 diabetes from knockout mouse models. J Clin Invest 2000, 106:459-465.

4. Han J, Inaguma T, Isoda H: Cyanidin 3-glucoside anthocyanin from black beans has potential to protect insulin resistance on 3T3-L1 adipocytes by inhibiting TNF-a release. Br J Nutr, (in press).

doi:10.1186/1753-6561-5-S8-P21

Cite this article as: Inaguma et al.: Improvement of insulin resistance by Cyanidin 3-glucoside, anthocyanin from black beans through the upregulation of GLUT4 gene expression. BMC Proceedings 2011 5(Suppl 8): P21
Submit your next manuscript to BioMed Central and take full advantage of:

- Convenient online submission

- Thorough peer review

- No space constraints or color figure charges

- Immediate publication on acceptance

- Inclusion in PubMed, CAS, Scopus and Google Scholar

- Research which is freely available for redistribution

Submit your manuscript at www.biomedcentral.com/submit
C Biomed Central 